\title{
Simulation of Runoff and Sediment Yield for a Kaneri Watershed Using SWAT Model
}

\author{
Vidula A. Swami, Sushama S. Kulkarni \\ Rajarambapu Institute of Technology, Sangli, India \\ Email: vidulaswami@gmail.com, sushma.kulkarni@ritindia.edu
}

Received 21 August 2015; accepted 22 December 2015; published 25 December 2015

Copyright (C) 2016 by authors and Scientific Research Publishing Inc.

This work is licensed under the Creative Commons Attribution International License (CC BY). http://creativecommons.org/licenses/by/4.0/

c) (i) Open Access

\begin{abstract}
Watershed as an entry point acts as a beginning to address the issues of sustainable rainwater management for improving livelihoods. Extraction of watershed parameters using Geographical Information System (GIS) and use of simulation models is the current trend for hydrologic evaluation of watersheds. In the present study, the open Source Tool Quantum GIS 2.2.0 was used for preparation of maps to verify the spatial extent of the area. The Soil and Water Assessment Tool (SWAT) having an interface with Arc-View GIS software (ArcGIS 10.1 with Arc SWAT 2012 extension) was selected for the estimation of runoff and sediment yield from Kaneri watershed, located in Western Maharashtra region. The coefficient of determination $\left(R^{2}\right)$ for the monthly and yearly runoff was obtained as 0.849 and 0.951 respectively for the calibration period 1979 to 2000 and 0.801 and 0.950 respectively for the validation period 2001-2013. The $R^{2}$ value in estimating the monthly and yearly sediment yield during calibration period was computed as 0.722 and 0.788 respectively. The $\mathbf{R}^{2}$ for monthly and yearly sediment yield values for validation period was observed to be 0.565 and 0.684 respectively.
\end{abstract}

\section{Keywords}

Arc SWAT, Calibration, Validation, GIS, Runoff, Sediment Yield, Coefficient of Determination $\mathbf{R}^{2}$

\section{Introduction}

Watershed as an entry point acts as a beginning to address the issues of sustainable rainwater management for improving livelihoods. To deal with water management issues, one must analyze and quantify the different elements of hydrologic processes taking place within the area of interest. Obviously, this analysis must be carried out on a watershed basis because all these processes are taking place within individual micro watersheds. Only after understanding the spatial and temporal variation and the interaction of these hydrologic components, one 
can scientifically formulate strategies for water and soil conservation. To achieve this goal, the choice and use of an appropriate watershed model is a must as stated by Sathian and Shyamala [1]. The Soil and Water Assessment Tool (SWAT) is a physically-based continuous daily step hydrologic model as mentioned by Arnold et al. [2] and Neitsch et al. [3] and is developed to assess the impact of land management practices on water, sediment, and agricultural chemical yields in large multifaceted watersheds with varying soils, land use and management conditions over long spans of time. Tripathi et al. [4] use it to predict water and soil loss in agriculturally dominant small watersheds. For assessing the impact of land management practices and climate on water flow and sediment yield in ungauged Kaneri watershed, Swami and Kulkarni [5] use SWAT (Soil and Water Assessment Tool) model in the study.

\subsection{Study Area}

Kaneri village is located in south Maharashtra region and is dominated by undulating plateau. It is located south-east to Kolhapur city on Pune-Bangalore highway in Maharashtra state. It is located at 16.6055 and $16.6412 \mathrm{~N}$ and 74.2535 and $74.2906 \mathrm{E}$ and is $11 \mathrm{kms}$ away from Kolhapur. It is surrounded by small hills. Figure 1 explains the location of the watershed. Geographical area of the village is 975.94 hectares. Kaneri lies in extreme elevation variation from $589 \mathrm{~m}$ to $692 \mathrm{~m}$. The village falls in agro-climatic zone IV and is characterized by rainfall ranging from 800 to $1000 \mathrm{~mm}$. The main occupation of the village is agriculture as $68.84 \%$ of the total area of village is under cultivation.

\subsection{SWAT Model}

The water balance is the driving force for the simulation of hydrology. SWAT uses two steps for the simulation

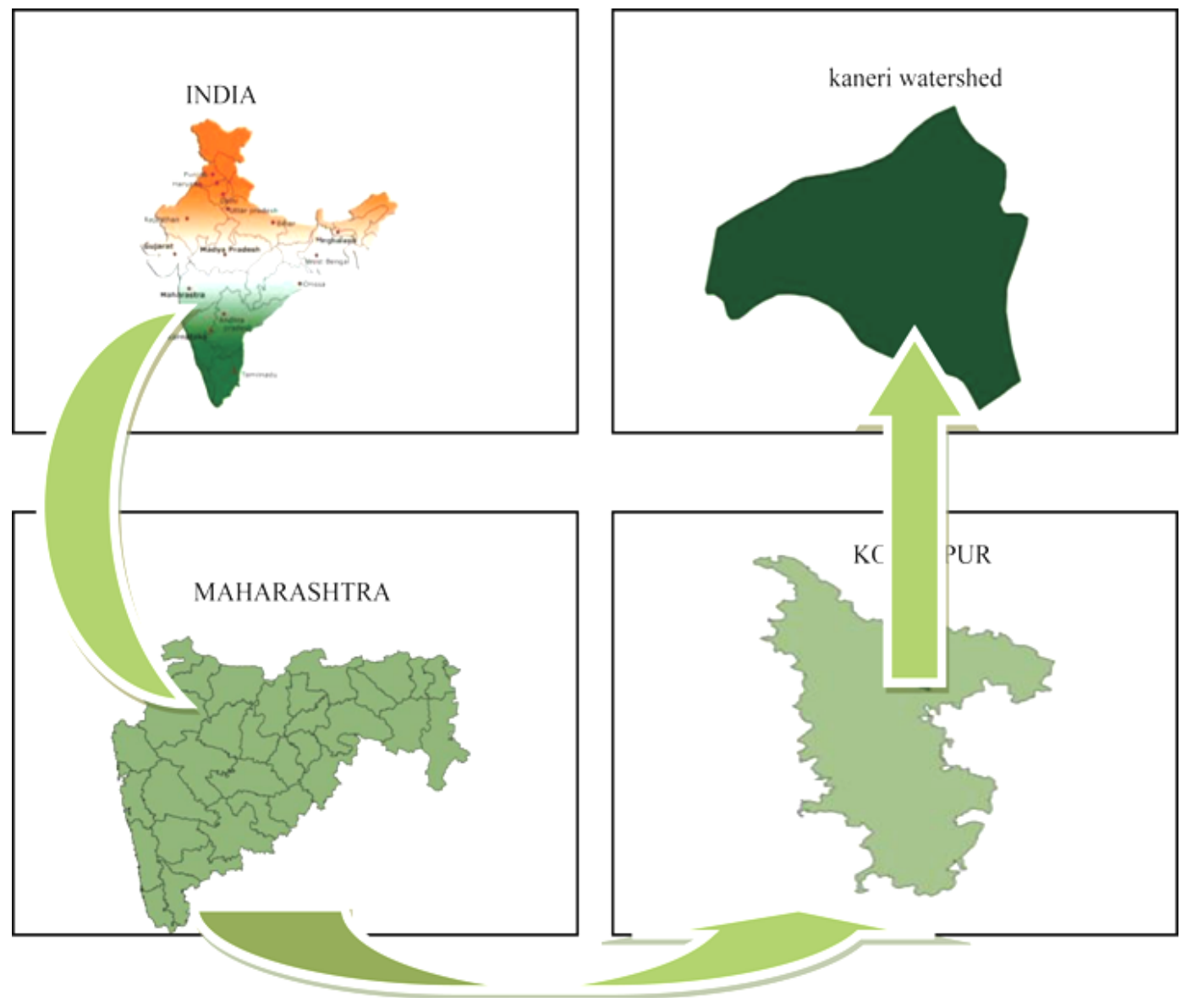

Figure 1. Location of Kaneri. 
of hydrology, land phase and routing phase. The land phase is the phase in which the quantity of water, sediment, nutrient and pesticides loadings in the main channel from each subbasin are calculated. Water balance equation for SWAT model is

$$
\mathrm{SW}_{\mathrm{t}}=\mathrm{SW}_{\mathrm{o}}+\sum\left(\mathrm{P}_{\text {day }}\right)-\mathrm{Q}_{\text {surt }}-\mathrm{AET}-\mathrm{Q}_{\text {seep }}-\mathrm{Q}_{\mathrm{gw}}
$$

where $\mathrm{SW}_{\mathrm{t}}$ is the final water content in millimeters, $\mathrm{SW}_{\mathrm{o}}$ is the initial soil water content on day $i(\mathrm{~mm}), \mathrm{P}_{\text {day }}$ is precipitation on day $i(\mathrm{~mm}), \mathrm{Q}_{\text {surf }}$ is surface runoff on day $i(\mathrm{~mm})$, AET is the actual evapo-transpiration on day $i$ $(\mathrm{mm}), \mathrm{Q}_{\text {seep }}$ is the water flowing into the unsaturated zone form the soil profile on day $i(\mathrm{~mm})$ and $\mathrm{Q}_{\mathrm{gw}}$ is the return flow from the shallow aquifer and lateral flow on day $i$ and $t$ is time in days [3]. In the present study, SWAT model is used for prediction of runoff and sediment yield in the micro watershed Kaneri. Santosh Kumbhar [6] estimated soil loss for Kaneri watershed as 17.67 Tonnes/Ha/Year, which is beyond the acceptable limits. Permissible soil loss given by Mannering (1981), is from 4.5 to 11.2 tonnes/ha/year.

SWAT model uses the concept that whenever the rate of water application to the ground surface exceeds the rate of infiltration, surface runoff occurs. SWAT uses the Modified Universal Soil Loss Equation (MUSLE) to estimate the soil loss from each HRU. The peak runoff rate is the highest runoff rate that occurs with a given precipitation event. SWAT calculates the peak runoff rate with a modified rational method. The factors $\mathrm{K}_{\mathrm{USLE}}$, $\mathrm{C}_{\text {USLE }}, \mathrm{P}_{\text {USLE }}, \mathrm{LS}_{\text {USLE }}$, and CFRG are taken and used based on previous studies on the watershed and the definition and calculations of the parameters presented in the SWAT documentation. Lateral flow is important in watersheds with soils with high hydraulic conductivities in surface layers and in impermeable or semi-permeable layer at a lesser depth. The water that collects above the impermeable layer is the spring of water for lateral subsurface flow [3].

SWAT calculates percolation for each layer in the profile and this process occurs only when the moisture content of the soil is more than field capacity. Recharge to an unconfined aquifer occurs by percolation to the water table from a major portion of the land surface. Depending on the water table height in the shallow aquifer, there is a base flow contribution to the main channel. This flow occurs only when the water stored in the shallow aquifer is greater than the threshold water level in the shallow aquifer for ground water input to the main channel to occur. This value is defined by the user or in the SWAT interface the variable is presented as GWQMN [3]. Integration of SWAT model with rainfall data available from the WSR 88 D radar network helps us to incorporate the spatial variability of rainfall into the modeling process. Four case studies were presented by Jay Krishnan et al. [7]. The study demonstrated the usefulness of radar rainfall data in distributed hydrologic studies and potential of SWAT for application in flood analysis and simulation.

Ashok Mishra et al. [8] used SWAT model to assess sediment transport from $17 \mathrm{~km}^{2}$ Banha watershed located in Northern India. Watershed has mixed land use and check dams are provided for on-stream sediment control. Model is run with and without check dams to test its capability to evaluate their impact on sediment control and proved to be successful. Weruweru catchment of drainage area $101 \mathrm{~km}^{2}$ with annual precipitation $1500 \mathrm{~mm}$ to $3000 \mathrm{~mm}$ at the foot slopes of Kilimanjaro in Northern Tanzania is studied for water balance modeling by using SWAT model. Model is performed on annual and monthly basis using spatial and attribute data. The predicted mean daily stream flow is found to be $1.92 \mathrm{~m}^{3} / \mathrm{sec}$. exactly as observed during simulation period. Birhanu et al. [9] shows in his study that SWAT model can be a potential monitoring tool for watersheds in hilly terrains. Samira Akhavan et al. [10] applied SWAT to simulate the amount and dynamics of nitrate leaching from a crop rotation in Hamadan-Bahar watershed, Iran, presented model and its results showed the potential to provide a strong base for considering different scenarios for reducing nitrate leaching and also for providing Best Management Practices (BMP) in the watersheds. An agricultural watershed of $0.8 \mathrm{Ha}$ area was studied for prediction of runoff flow using SWAT tool with sub daily configuration which assessed flow from the watershed within the range of acceptable accuracy. Ganga Ram Mahajan et al. [11] showed that hourly precipitation record for SWAT sub daily with Green Ampt infiltration method was found to be efficient for run off estimation for field sized watershed with better accuracies which could be efficiently used to develop site specific Best Management Practices (BMPs) considering rainfall intensity rather than simply using daily rain fall data.

\section{Methodology}

\subsection{Creation of Database}

To delineate the watershed and sub basins and to determine drainage networks SWAT uses the digital represen- 
tation of the topographic surface. DEM is the digital representation of the topographic surface. A $30 \mathrm{~m}$ by $30 \mathrm{~m}$ resolution ASTERDEM was derived and re-sampled to $15 \mathrm{~m} \times 15 \mathrm{~m}$ for ease in data acquisition. Figure 2 shows DEM of Kaneri village. Sub basin parameters such as slope gradient, slope length of terrain and the stream network characteristics such as channel length, width and slope were calculated for the base village area and used by the model. Figure 3 gives drainage map of Kaneri village.

A land use map was created by recording the crop type on each plot in the watershed and by identifying the land cover on areas other than cultivated fields. LULC map was acquired from LISS III (Linear Imaging and Self Scanning Sensors). The digital Google image was geo-referenced by taking control points around and inside the watershed. The shape file representing each plot and other land covers was created using the digitizing tools provided in ArcGIS, ArcMap. The soil map obtained from the NBSS\&LUP was geo-metrically registered to the base data to match Landsat \& IRS satellite imageries. The geo-referenced soil map was used to assist in visual classification of satellite imagery for obtaining soil categories. The final vector map was stored in a geodatabase which is amenable to spatial analyze.

SWAT requires daily or sub-daily meteorological data. For Kaneri watershed the daily climate data from two rain gauge stations was used. Daily rainfall data was used for SWAT Model Run. Multiple Gauges were used for weather data input. The main inputs used for weather data in the model are gridded rainfall and temperature. The curve number method (USDA-SCS, 1986) was chosen for calculating runoff. Penman-Monteith method (Monteith, 1965) was chosen for calculating potential evapotranspiration. The variable storage method was chosen as the channel routing mechanism with the assumption that channel dimensions remain constant. The model was set to run from 1st January 1979 to 31st July 2014 with a monthly printout interval. By considering the drainage lines the stream network was prepared. The watershed outlet was manually added and selected for finalizing the watershed delineation (Figure 4). With this information the model automatically delineated a watershed of 535.48 ha and 28 sub basins were produced. Multiple HRUs were defined within a sub basin by ignoring land uses less than $2 \%$ of the subbasin and also ignoring soil types in a subbasin covering less than $5 \%$ of the subbasin. Figure 5 shows land use land cover map of Kaneri watershed.

The watershed of total area $535.48 \mathrm{Ha}$ has been classified in following land uses (Table 1).

Land use map is a critical input for SWAT model. Land use/land cover map was prepared using remote sensing data of Landsat ETM+. The classification of satellite data mainly follows two approaches i.e. supervised and unsupervised classification. The intent of the classification process is to categorize all pixels in a digital image into one of several land cover classes, or themes [12]. The detailed Sub Basin wise land use distribution is as in

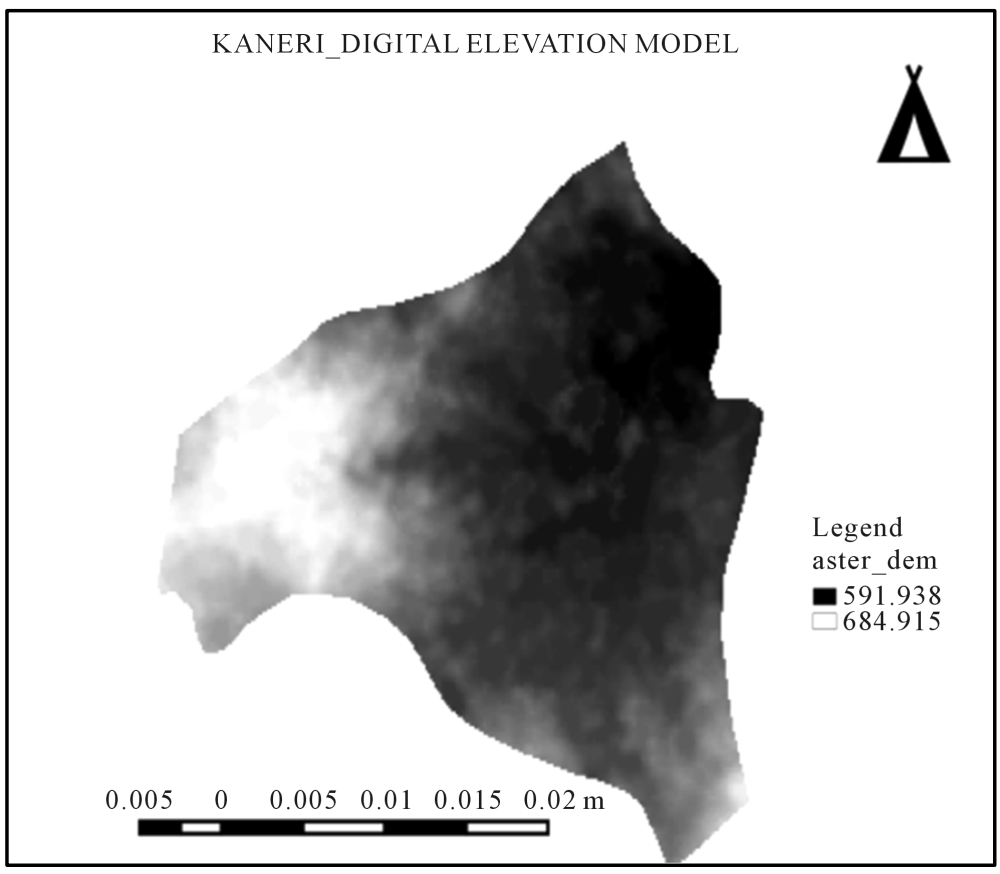

Figure 2. Digital elevation model of Kaneri. 


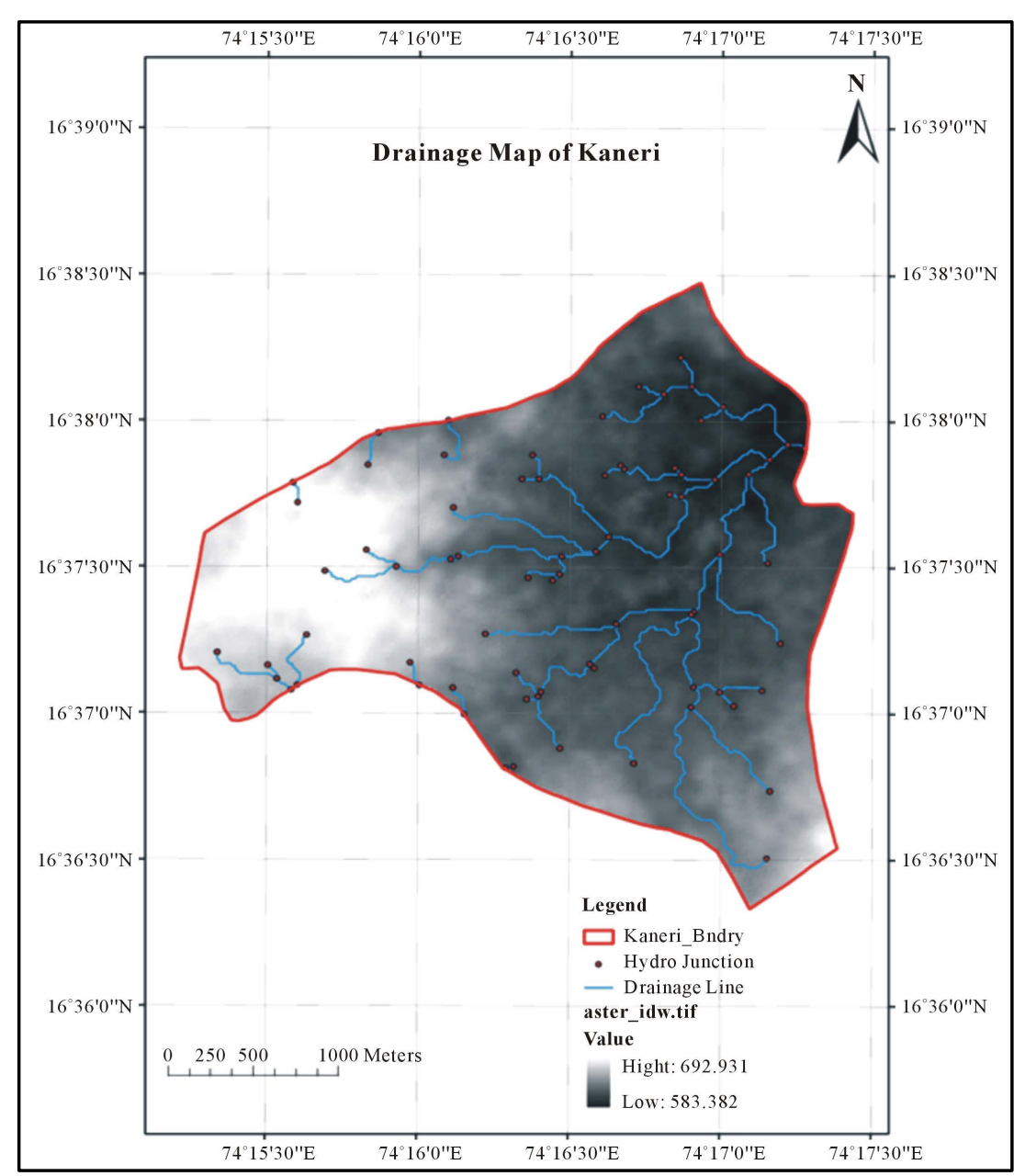

Figure 3. Drainage map of Kaneri Village.

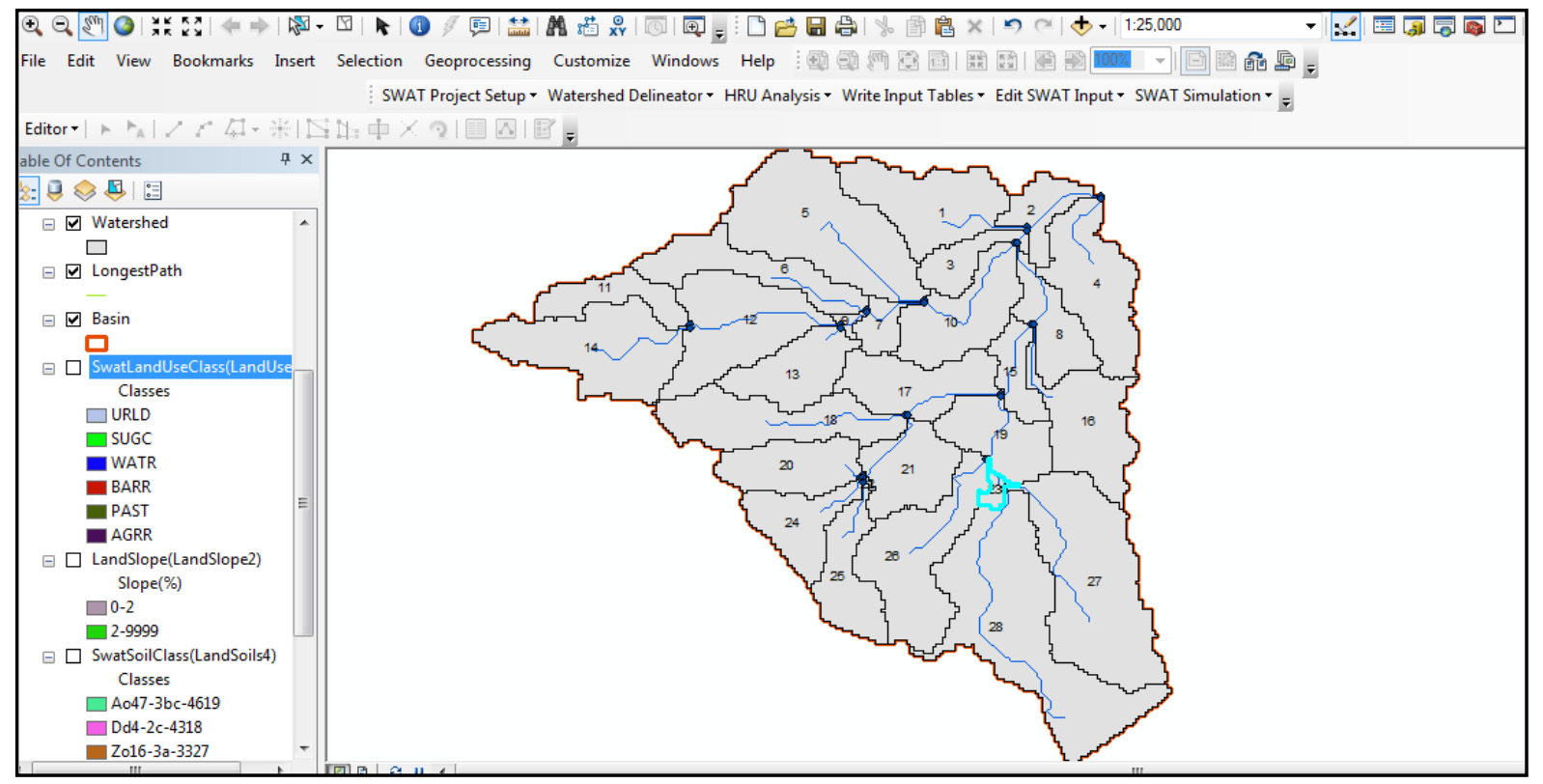

Figure 4. Watershed delineation map. 


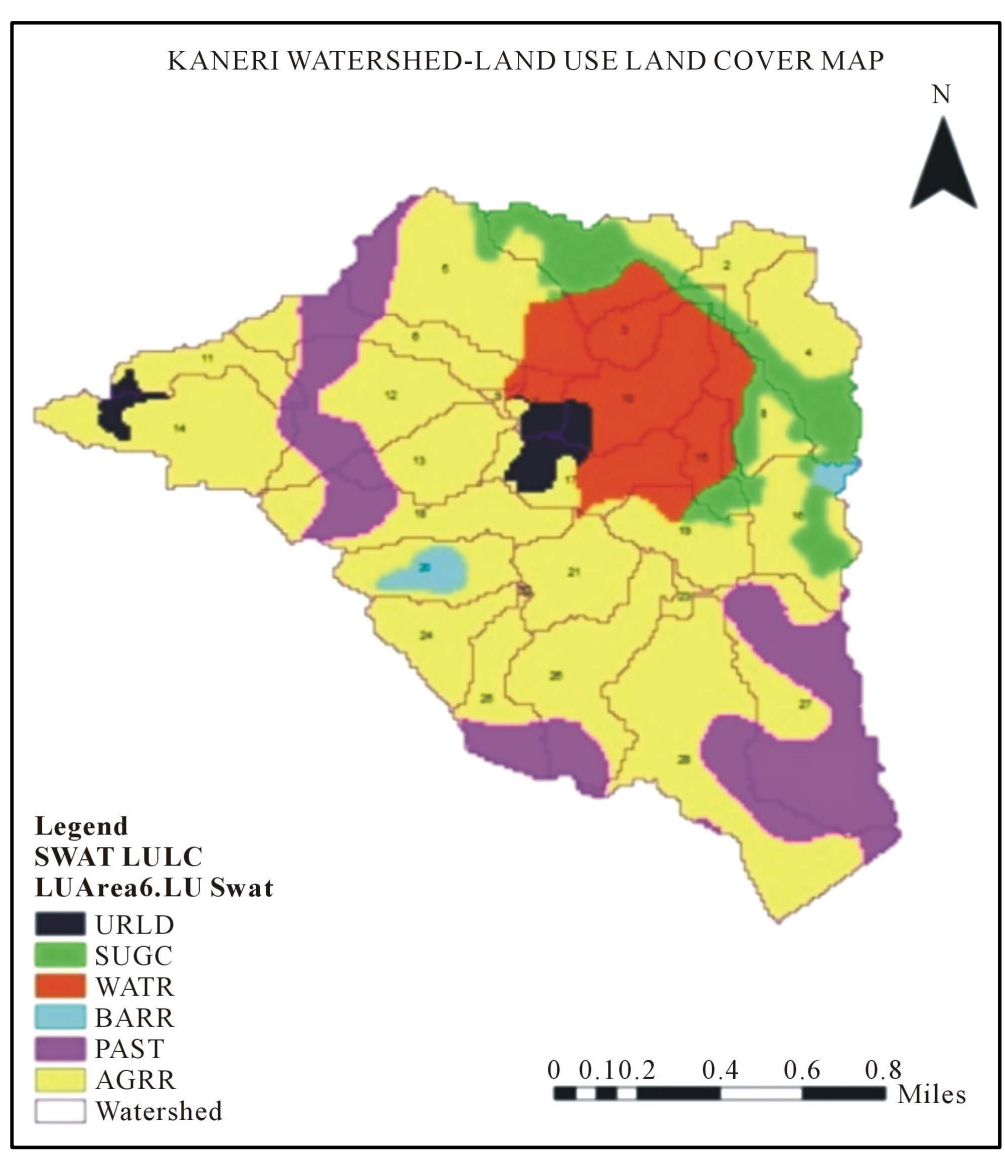

Figure 5. LULC of Kaneri Watershed.

Table 1. Land use classification with total area distribution.

\begin{tabular}{ccccc}
\hline Sr. No. & Land Use Category & Code & Area (Ha) & \% of Watershed Area \\
\hline 1 & Urban Residential Low density & URLD & 11.93 & 2.228 \\
2 & Sugarcane & SUGC & 37.84 & 7.069 \\
3 & Water bodies & WATR & 64.20 & 11.99 \\
4 & Barren & BARR & 85.25 & 15.919 \\
5 & Pasture & PAST & 5.72 & 1.069 \\
6 & Agriculture Land & AGRR & 330.54 & 61.724 \\
\hline
\end{tabular}

Table 2. This categorized data may then be used to produce thematic maps of the land cover present in an image.

\subsection{Model Setup}

SWAT allows the user to delineate the watershed and sub basins using the Digital Elevation Model (DEM). Drainage network is also prepared which can be useful for delineation. Figure 3 shows the drainage map of Kaneri Watershed. Figure 4 gives delineated watershed through Arc-SWAT. The delineated watershed by Arc SWAT and the prepared land use map overlapped 100\%. Figure 6 shows Land Use Land Cover map overlay. For runoff to produce, the basic necessity of the model is to have the total rainfall more than field capacity of the soil. If it is less, then the subsurface flow is modeled. SWAT runs for both the possibilities and computes peak rate, transmission losses and sediment yield in first case and computes soil water routing, evapo-transpiration, crop growth, pond, wetland balances, ground water flow in the second case. While running the model land use 
Table 2. Detailed sub basin wise land use distribution of Kaneri Watershed.

\begin{tabular}{|c|c|c|c|c|c|c|c|}
\hline OID & SUBBASIN & URLD & SUGC & WATR & PAST & BARR & AGRR \\
\hline 1 & 1 & & 12.27188 & 5.145494 & & & 6.739872 \\
\hline 2 & 2 & & 0.724717 & & & & 8.261779 \\
\hline 3 & 3 & & 0.917975 & 7.053916 & & & 0.338201 \\
\hline 4 & 4 & & 9.711213 & 0.096629 & 0.096629 & & 14.97749 \\
\hline 5 & 5 & & 1.594378 & 7.005602 & & 6.329199 & 26.25893 \\
\hline 6 & 6 & & & 0.507302 & & 4.56572 & 12.92413 \\
\hline 7 & 7 & 2.19831 & & 2.391567 & & & 0.70056 \\
\hline 8 & 8 & & 4.082575 & 4.855607 & & & 4.29999 \\
\hline 9 & 9 & & & 0.26573 & & & 0.748875 \\
\hline 10 & 10 & 2.149995 & 0.144943 & 18.45614 & & & \\
\hline 11 & 11 & 0.773032 & & & & 0.628088 & 9.590427 \\
\hline 12 & 12 & & & & & 9.759528 & 18.72187 \\
\hline 13 & 13 & & & & & 2.174152 & 13.72132 \\
\hline 14 & 14 & 2.294939 & & & & 0.869661 & 27.75668 \\
\hline 15 & 15 & & 1.956737 & 5.870211 & & & 0.26573 \\
\hline 16 & 16 & & 5.580324 & 1.256177 & 1.521907 & 0.144943 & 13.45559 \\
\hline 17 & 17 & 4.517405 & & 8.817395 & & & 5.459538 \\
\hline 18 & 18 & & & & & 6.280884 & 18.38367 \\
\hline 19 & 19 & & 0.869661 & 2.439882 & & & 12.19941 \\
\hline 20 & 20 & & & & 4.106732 & & 11.76458 \\
\hline 21 & 21 & & & 0.048314 & & & 16.30614 \\
\hline 22 & 22 & & & & & & 0.169101 \\
\hline 23 & 23 & & & & & & 1.811794 \\
\hline 24 & 24 & & & & & & 14.32525 \\
\hline 25 & 25 & & & & & 5.483695 & 9.276383 \\
\hline 26 & 26 & & & & & 5.169651 & 24.49545 \\
\hline 27 & 27 & & & & & 33.02296 & 12.75503 \\
\hline 28 & 28 & & & & & 10.82245 & 44.83585 \\
\hline
\end{tabular}

land cover map, soil map, slope map and weather data is provided as an input on which the processing is done through SWAT model.

Modeling process once over, gives the output in the form of surface runoff, PET (Potential Evapo Transpiration), Evapo Transpiration, Percolation, Ground water flow, Soil Moisture, Water Yield and Sediment Yield. In this study by Ashok Mishra et al. [8], the estimated runoff and sediment yield from each sub-watershed were compared with measured values and the effect of LU/LC, soil and topographic characteristics was then evaluated. Figure 7 shows soil map overlay for SWAT model setup.

Multiple HRUs were defined within a sub basin by ignoring land uses less than $2 \%$ of the subbasin and also ignoring soil types in a subbasin covering less than $5 \%$ of the subbasin. A total of 76 HRUs for 28 sub basins were created. Figure 8 shows slope map overlay of Kaneri Watershed.

SWAT tool having an interface with Arc View GIS software (AVSWAT 2000) was used by Jain S. K. et al. [12] for runoff and sediment yield from area of Suni to Kasol, watersheds of satluj river, western Himalaya, performed well for runoff prediction. Coefficient of determination $\left(\mathrm{R}^{2}\right)$ for daily and monthly runoff was 0.53 and 0.90 respectively for calibration period (1993-1994) and 0.33 and 0.62 respectively for validation period (1995 to 1997) $R^{2}$ values in estimating daily and monthly sediment yield during calibration period was found as 0.33 and 0.38 respectively, and for validation period it was observed 0.26 and 0.47 respectively showing a little low performance for sediment yield estimation. 


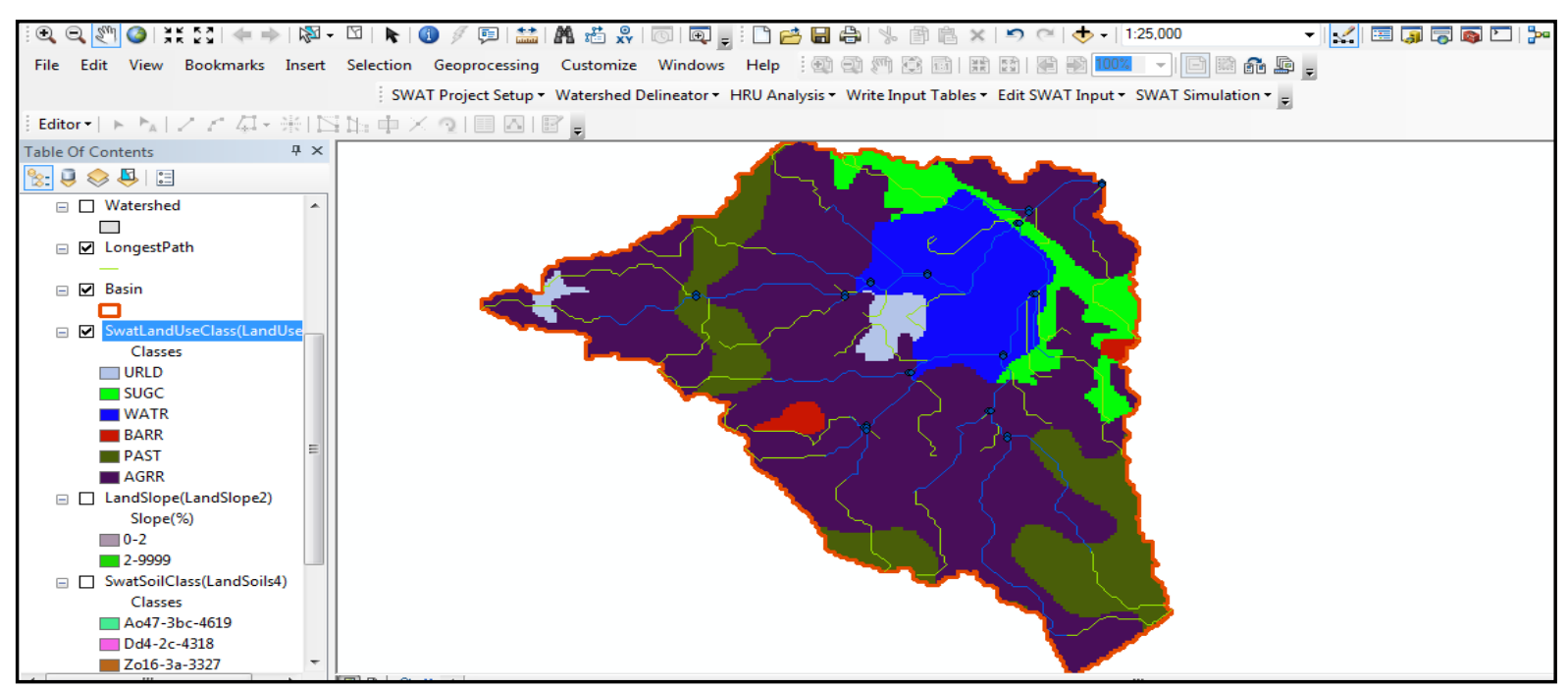

Figure 6. Land use land cover map overlay for SWAT model setup.

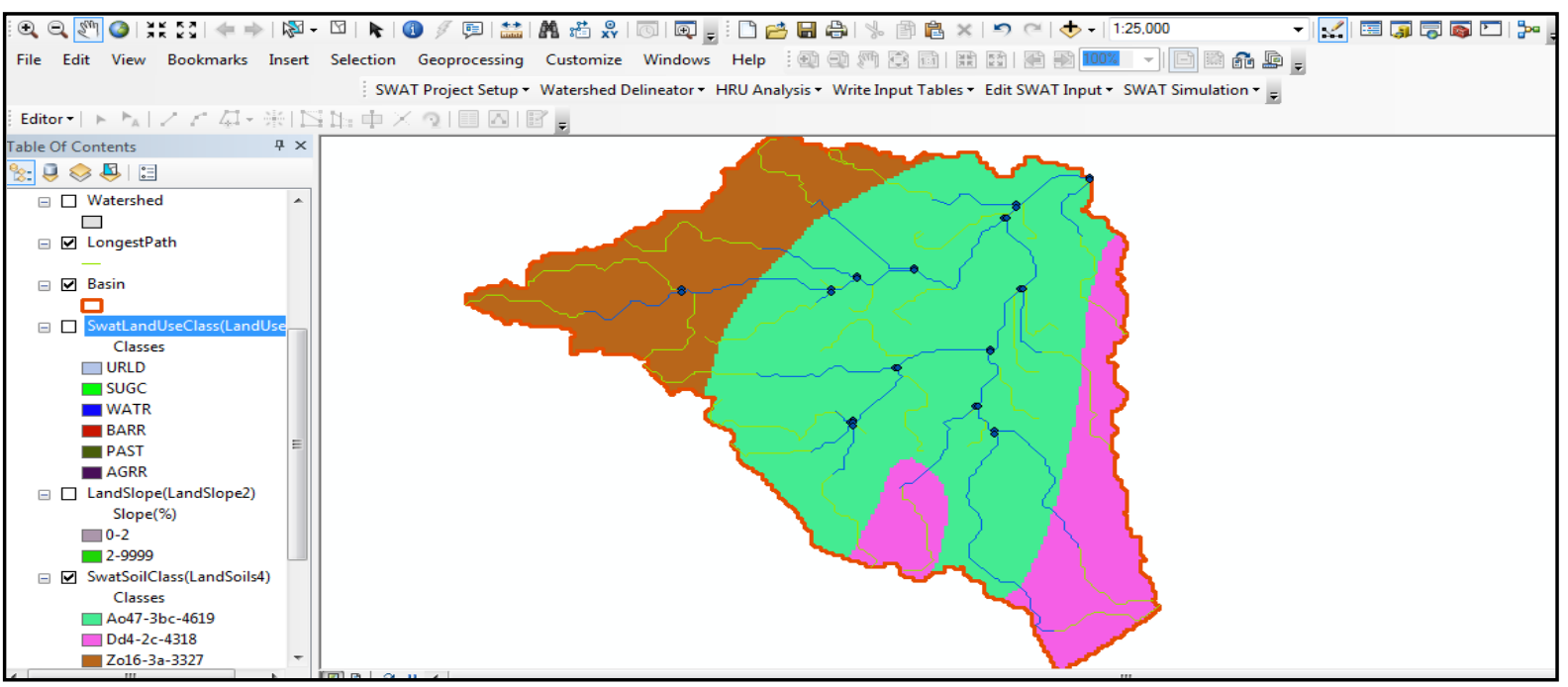

Figure 7. Soil map overlay for SWAT model setup.

Narayan K. Shreshtha et al. [13] examined SWAT model performance of Kilene Nete Watershed Belgium with area 581 sq. km. Seven SWAT model parameters were calibrated (1994-1998) and validated (1999-2002). The Parameter Ch_K $\mathrm{K}_{2}$ (Channel effective hydraulic conductivity) was found to be the most sensitive. $\mathrm{R}^{2}$ and NSE values for calibration and validation were found to be 74 and 67 percent respectively, showing satisfactory goodness of fit statistics. Puwadon Phomcha et al. [14], while simulating monthly stream flow in Lam Sonthi watershed in Thailand found $\mathrm{R}^{2}$ and NSE values greater than 0.7 and deviation of runoff volumes with acceptably accurate values. Some months of simulated flows showed over estimated values but most simulated flows were close to observed flows by both visual and statistical approaches.

Calibration and validation of a SWAT model applied by Arun Babu et al. [15] for Krishnagiri Reservoir Watershed, TamilNadu were carried for testing model performance. Model Calibration (2000-2005) and validation (2006-2010) were carried by using the measured discharge and sediment load from a gauge station. It showed a satisfactory agreement between the measured monthly flow with simulated flow values with $\mathrm{R}^{2}$ value 0.9 and NSE value 0.8. For a small agricultural watershed in Tamilnadu, India, SWAT model was applied by Kaviya K. et al. [16] for prediction of water balance parameters. The investigation was carried out using a 10 year rainfall record from Jan. 88-Jan. 98 for calibration and validation. Model performed well with $\mathrm{R}^{2}$ value greater than 0.98 and correlation coefficient value greater than 0.9 . 


\subsection{Performance Evaluation of the Model}

For calibration and validation, different techniques are being used. In the present study, conventional method along Arc SWAT tool was used. The main function of an interface is to provide a link between the input/output of a calibration program and the model. The simplest way of handling the file exchange is through text file formats. The model was run for thirty six years 1979 to 2014. Surface runoff and sediment calibration for the Kaneri watershed was conducted for the years 1979 to 2000. Similarly, surface runoff and sediment validation for the Kaneri watershed was carried out for the years 2001 to 2013. The most widely used criteria, for testing performance of a model is coefficient of determination $\mathrm{R}^{2}$

$$
\mathrm{R}^{2}=\frac{\left[\sum\left(\mathrm{Q}_{\text {sim i }}-\mathrm{Q}_{\text {asim i }}\right)\left(\mathrm{Q}_{\mathrm{obsi}}-\mathrm{Q}_{\mathrm{aobsi}}\right)\right]^{2}}{\sum\left(\mathrm{Q}_{\text {sim i }}-\mathrm{Q}_{\text {asim i }}\right)^{2} \sum\left(\mathrm{Q}_{\mathrm{obs}}-\mathrm{Q}_{\text {aobs i }}\right)^{2}}
$$

where,

$\mathrm{R}^{2}=$ coefficient of determination;

$\mathrm{Q}_{\text {obsi }}=$ Observed value at time step $i$;

$\mathrm{Q}_{\operatorname{sim} \mathrm{i}}=$ Simulated value at time step $i$;

$\mathrm{Q}_{\text {aobsi }}=$ Average of observed value at time step $i$;

$\mathrm{Q}_{\mathrm{asim} \mathrm{i}}=$ Average of simulated value at time step $i$.

$\mathrm{R}^{2}$ describes the percentage of the variance in calculated data experienced by the model. According to the criteria developed by Sameh et al. [17] $\mathrm{R}^{2}$ ranges from 0 to 1, with greater values indicating low error variance, and typically values greater than 0.5 are considered acceptable. Krause et al. [18] stated that $\mathrm{R}^{2}$ statistic provided an estimate of how well the variance of measured values are replicated by model predictions. The general performance rating criteria developed by Sameh et al. [17] for calibration and validation of SWAT model are given in Table 3.

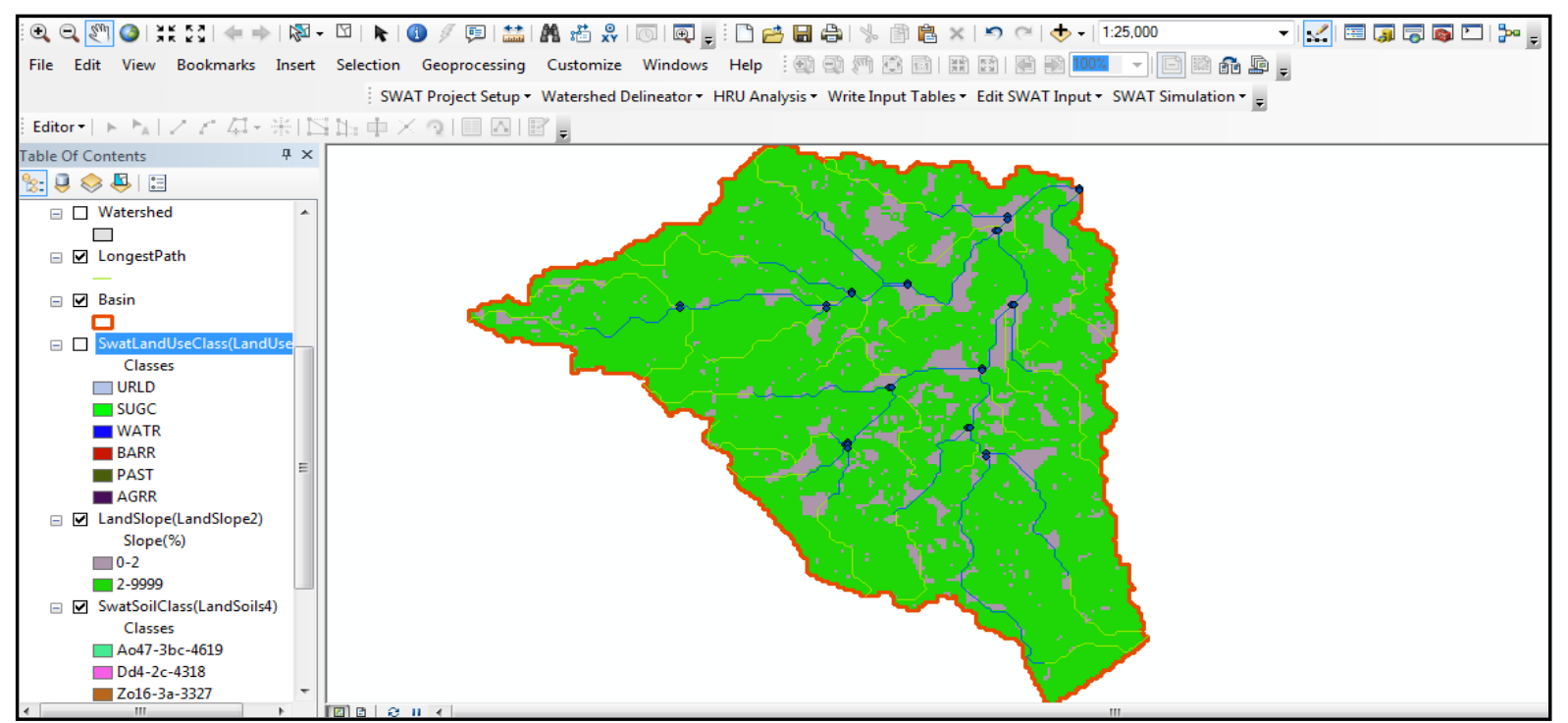

Figure 8. Slope map overlay for SWAT model setup.

Table 3. Performance rating for calibration and validation of SWAT model.

\begin{tabular}{cc}
\hline Performance rating & $\mathrm{R}^{2}$ \\
\hline Very Good & $\mathrm{R}^{2}>0.70$ \\
Good & $0.60<\mathrm{R}^{2} \leq 0.70$ \\
Satisfactory & $0.50<\mathrm{R}^{2} \leq 0.60$ \\
Unsatisfactory & $\mathrm{R}^{2}<0.50$ \\
\hline
\end{tabular}


The model goodness-of-fit was evaluated on a yearly and monthly basis. The linear graphs for the measured and simulated values both for flow and sediment on yearly basis for calibration and validation are presented. The linear graphs for the measured and simulated values both for flow and sediment on monthly basis for calibration and validation are also produced.

\section{Results and Discussion}

\subsection{Model Calibration}

The SWAT model was calibrated using the yearly data of runoff and sediment yield recorded at the outlet of the study watershed for the years 1979 to 2000. Several simulation runs were applied to achieve the model calibration. The time series of the observed and simulated monthly sediment yield for the calibration period were plotted for visual comparison (Figure 9 and Figure 10). The total monthly runoff computed by the model was, found to be $6792.11 \mathrm{~mm}$ against the observed runoff of $6992.77 \mathrm{~mm}$ during 1979 to 2000. The sediment yield computed by the model during respective months was obtained as $124.61 \mathrm{t} / \mathrm{ha}$ against the observed sediment yield of $118.26 \mathrm{t} / \mathrm{ha}$.

The observed and predicted values were plotted against each other in order to determine the goodness-of fit criterion of coefficient of determination $\left(\mathrm{R}^{2}\right)$ both for runoff and sediment yield. The $\mathrm{R}^{2}$ for yearly and monthly values was obtained as 0.951 and 0.849 respectively for runoff (Figure 11(a), Figure 11(b)) and 0.788 and 0.722 respectively for sediment yield (Figure 11(c) and Figure 11(d)). It was reported that SWAT's yearly flow predictions, in general, were not as good as monthly flow predictions.

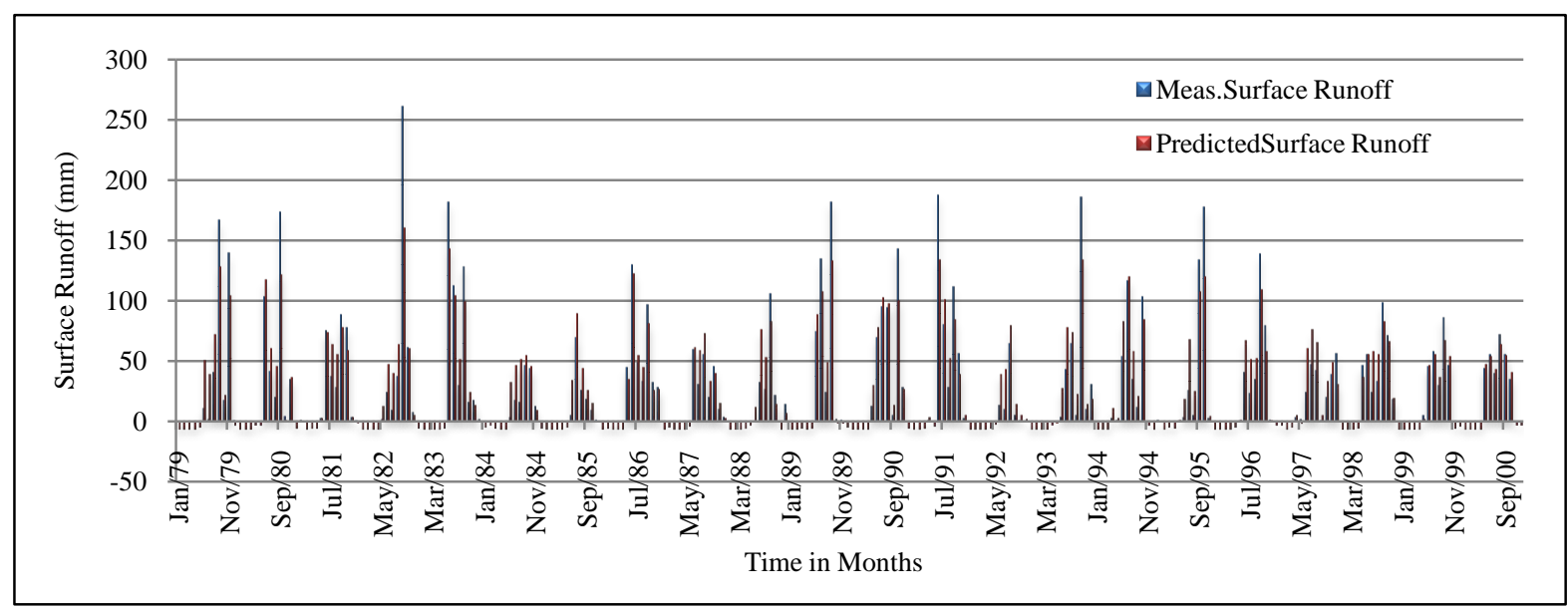

Figure 9. Measured and predicted surface runoff for calibration period 1979-2000.

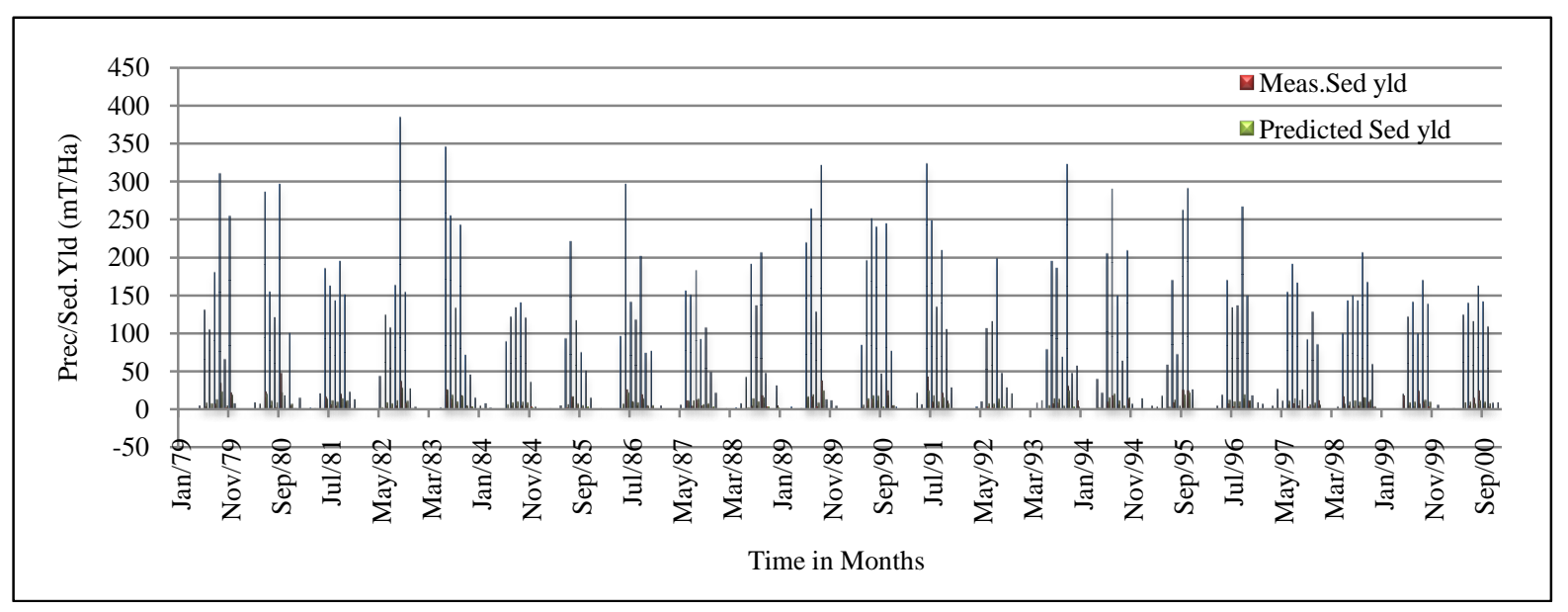

Figure 10. Measured and predicted sediment yield for calibration period 1979-2000. 


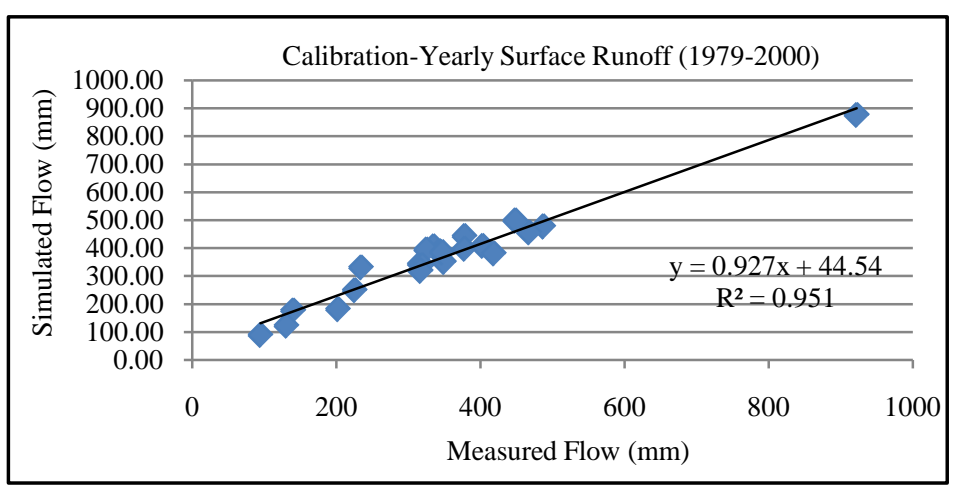

(a)

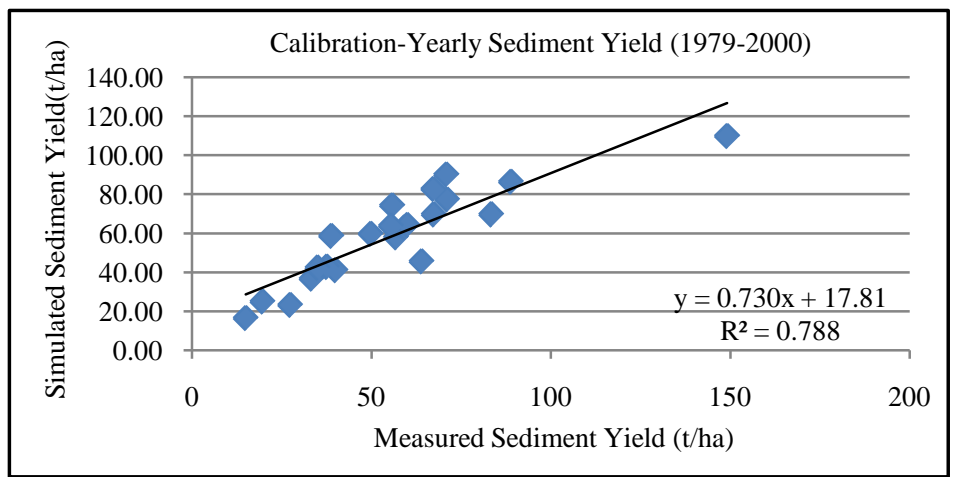

(b)

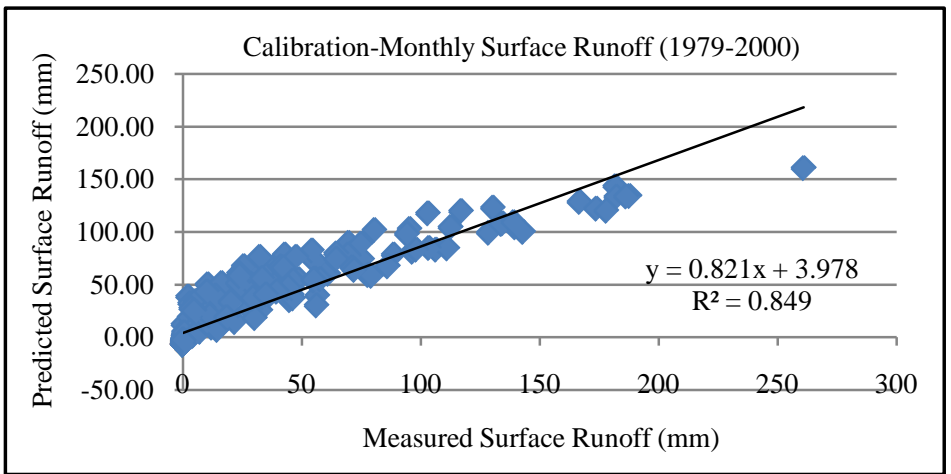

(c)

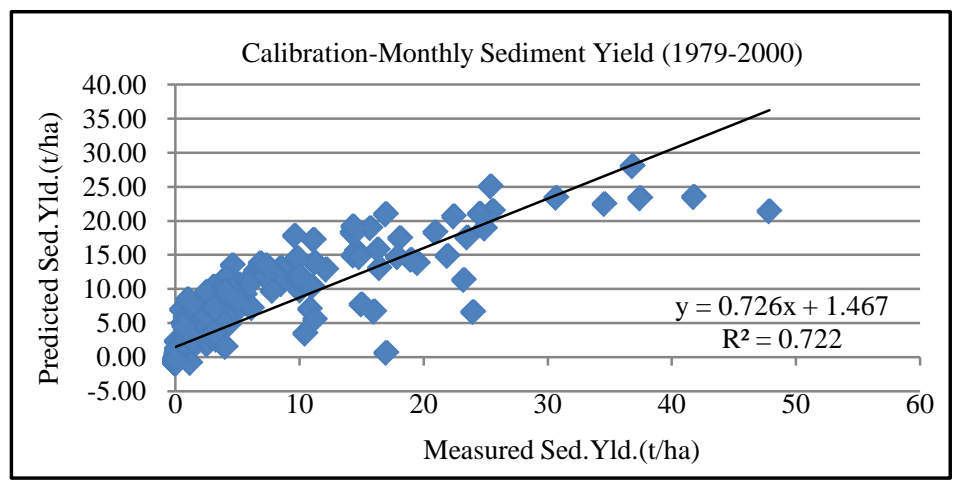

(d)

Figure 11. (a) Determination of coefficient of determination for yearly surface runoff; (b) Determination of coefficient of determination for yearly sediment yield; (c) Determination of coefficient of determination for monthly surface runoff; (d) Determination of coefficient of determination for yearly sediment yield. 


\subsection{Model Validation}

The model validation was carried out for yearly and monthly surface runoff and sediment yield for the years 2001 to 2013. A graphical comparison of the observed and simulated yearly and monthly flows and sediment yield are shown in Figure 12 and Figure 13.

The total monthly surface runoff computed by the model was, found to be $3228.04 \mathrm{~mm}$ against the observed runoff of $3027.38 \mathrm{~mm}$ during 2001 to 2013. The sediment yield computed by the model during respective months was obtained as $60.06 \mathrm{t} / \mathrm{ha}$ against the observed sediment yield of $66.40 \mathrm{t} / \mathrm{ha}$. The observed and predicted values were plotted against each other in order to determine the goodness-of fit criterion of coefficient of determination $\left(\mathrm{R}^{2}\right)$ both for runoff and sediment yield. The $\mathrm{R}^{2}$ value for monthly and yearly surface runoff was obtained as 0.801 and 0.950 respectively (Figure 14(a), Figure 14(b)) and 0.565 and 0.684 respectively for sediment yield (Figure 14(c) and Figure 14(d)). It was reported that SWAT's yearly flow predictions, in general, were better than monthly flow predictions.

\section{Conclusions}

In the present study, The Soil and Water Assessment Tool (SWAT) having an interface with Arc-View GIS software (ArcGIS 10.1 with Arc SWAT 2012 extension), was applied to the hilly watershed for modeling runoff and sediment yield. After preparing all the thematic maps and database as per the format of AVSWAT model,

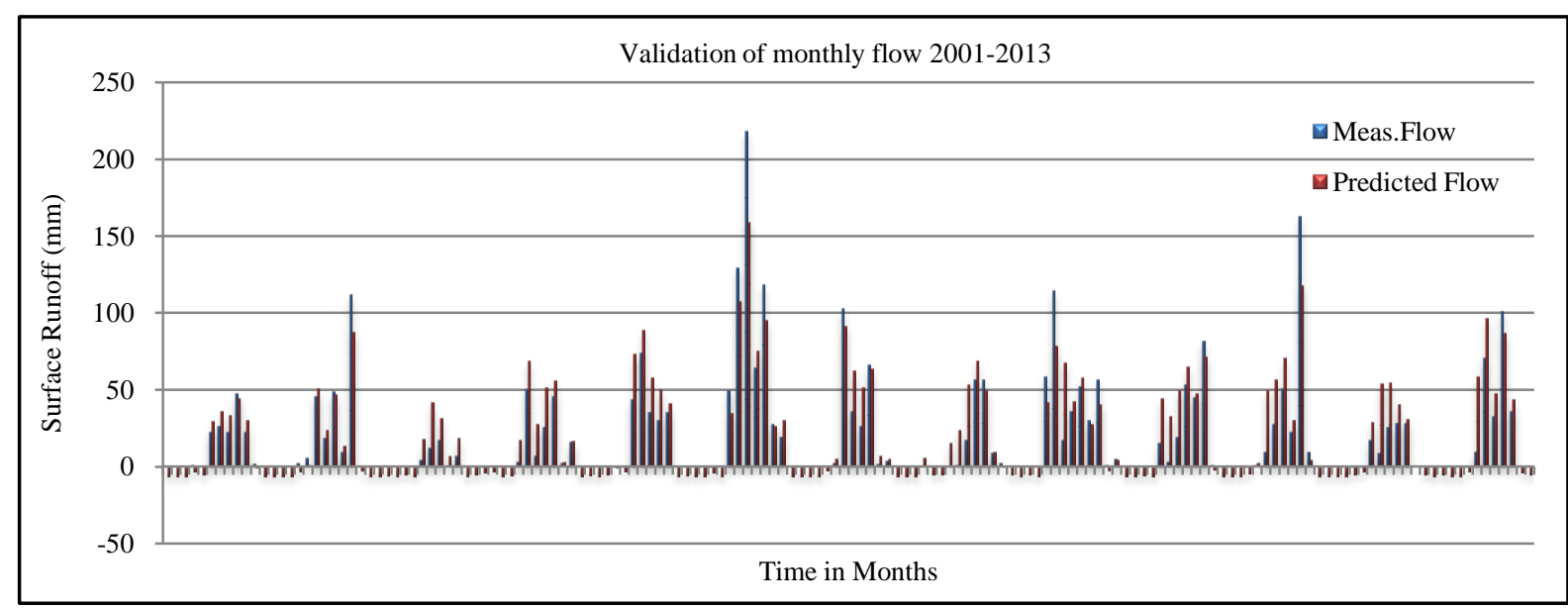

Figure 12. Measured and predicted surface runoff for validation period 2001-2013.

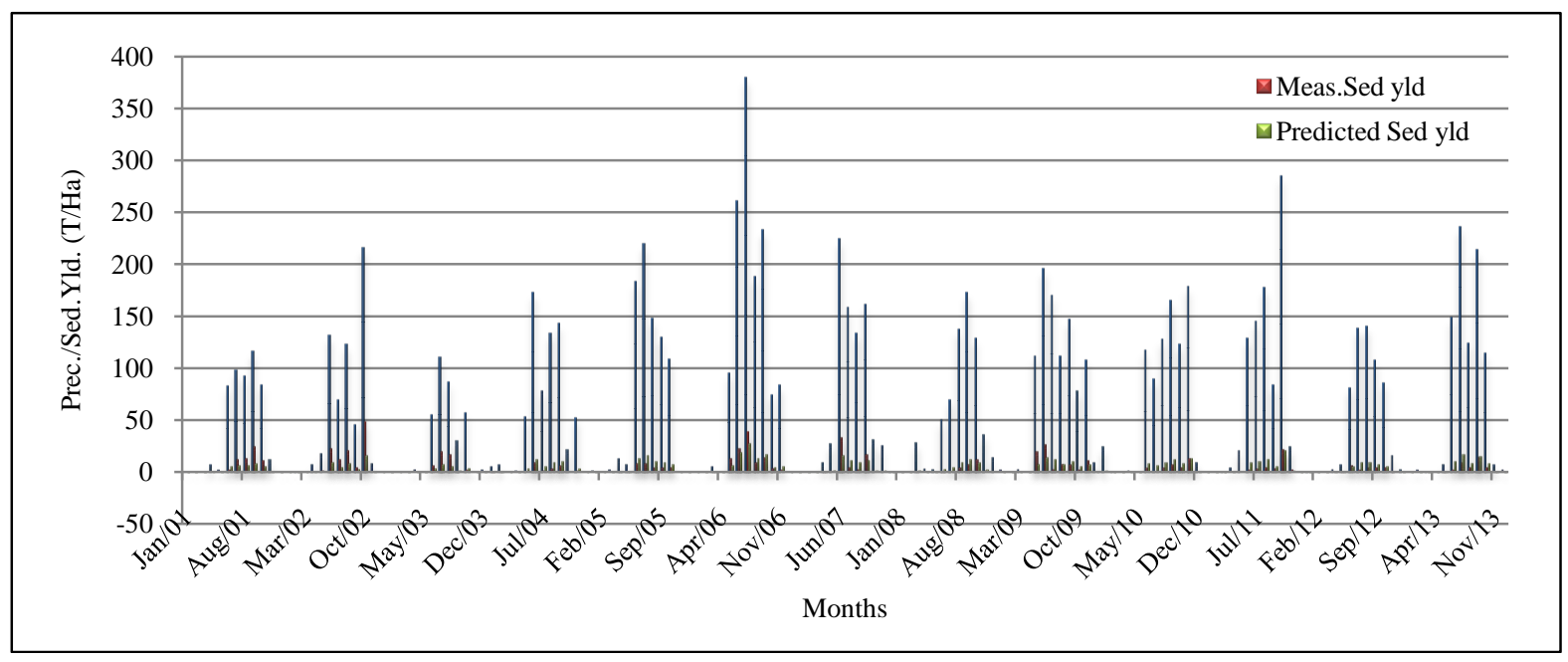

Figure 13. Measured and predicted sediment yield for validation period 2001-2013. 


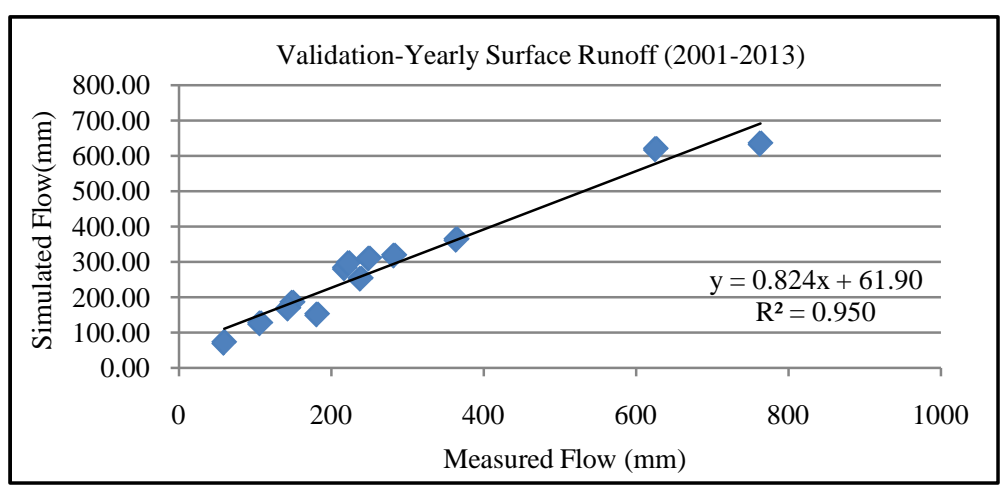

(a)

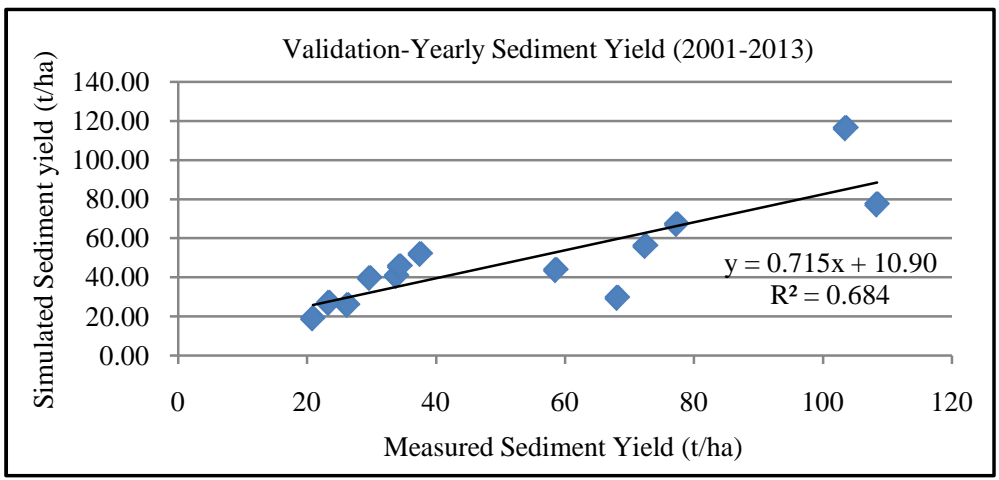

(b)

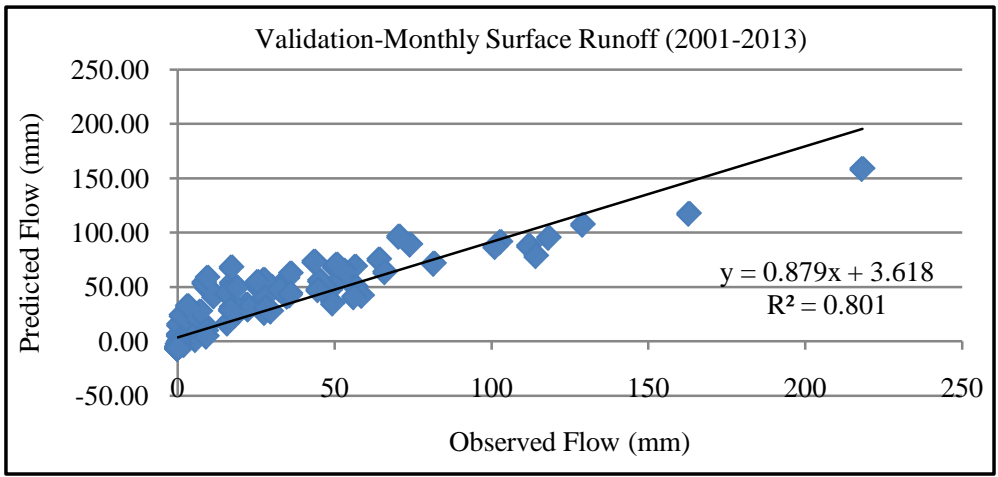

(c)

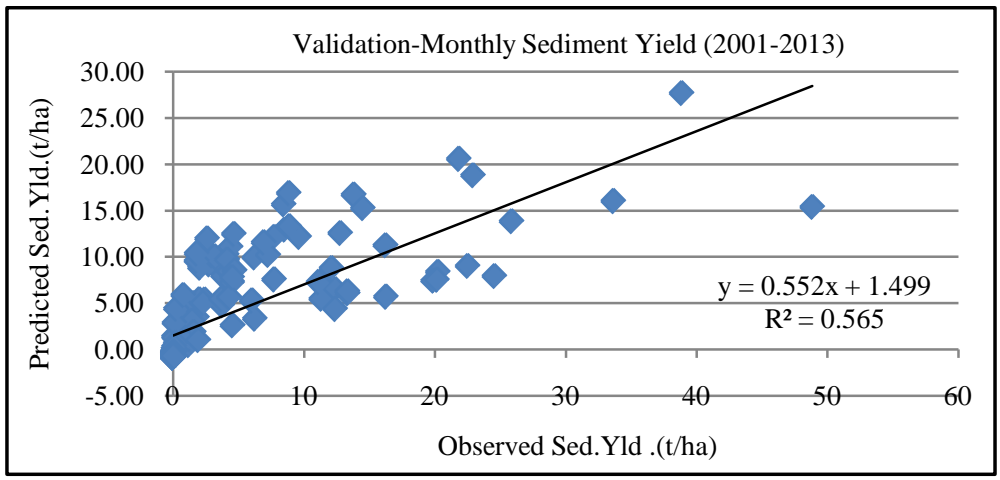

(d)

Figure 14. (a) Determination of coefficient of determination for yearly surface runoff; (b) Determination of coefficient of determination for yearly sediment yield; (c) Determination of coefficient of determination for monthly surface runoff; (d) Determination of coefficient of determination for monthly sediment yield. 
the model was calibrated for the yearly and monthly surface runoff and sediment yield using the observed data of 1979 to 2000. The model validation was carried out for a data set of thirteen years of 2001 to 2013. The simulation performance of the model for calibration and validation was evaluated using graphical and statistical methods.

The coefficient of determination $\left(\mathrm{R}^{2}\right)$ for the yearly and monthly runoff was obtained as 0.849 and 0.951 respectively for the calibration period and 0.801 and 0.950 respectively for the validation period. The $\mathrm{R}^{2}$ value in estimating the yearly and monthly sediment yield during calibration was computed as 0.722 and 0.788 respectively. The $\mathrm{R}^{2}$ for yearly and monthly sediment yield values during validation period was observed to be 0.565 and 0.684 . Thus, the values of $\mathrm{R}^{2}$ can be considered satisfactory for estimating runoff and sediment yield from a hilly watershed with available data.

\section{References}

[1] Sathian, K.K. and Shyamala, P. (2009) Application of GIS Integrated SWAT Model for Basin Level Water Balance. Indian Journal of Soil Conservation, 37, 100-105.

[2] Arnold, J.G., Moriasi, D.N., Gassman, P.W., Abbaspour, K.C., White, M.J., Srinivasan, R., Santhi, C., Harmel, R.D., Van Griensven, A., Van Liew, M.W., Kannan, N. and Jha, M.K. (2012) SWAT Model Use: Calibration and Validation. Transactions of the ASABE, 55, 1491-1508. http://dx.doi.org/10.13031/2013.42256

[3] Neitsch, J.R., Arnold, J.G., Kiniry, J.R. and Williams, J.R. (2005) Input/Output File Documentation Version 2005. User Manual Grassland, Soil and Water Research Laboratory, Agricultural Research Service, Blackland Research Center, Texas Agricultural Experiment Station, Temple, Texas.

[4] Tripathi, C.N. and Goasin, A.K. (2003) Micro Watershed Modeling in India Using GIS Technologies and Agricultural Policy Environmental Extender (APEX) Model-A Case Study. International Journal of Engineering Research and Application, 3, 1640-1648.

[5] Swami Vidula, A. and Kulkarni Sushma, S. (2014) Evaluation of the Best Management Practices Using SWAT Model for the Kaneri Micro-Watershed, Southern Maharashtra, India. International Journal of Advanced Technology in Engineering and Science, 2, 9-16.

[6] Kumbhar, S. (2011) Watershed Development Plan for Kaneri Watershed. M.E. Thesis, Rajarambapu Institute of Technology, Sakharale.

[7] Jay Krishnan, R., Sriniwasan, R., Santhi C. and Amold, J.G. (2005) Advances in the Application of the SWAT Model for Water Resources Management. Hydrological Processes, 19, 749-762. http://dx.doi.org/10.1002/hyp.5624

[8] Mishra, A., Kar, S. and Singh, V.P. (2007) Prioritizing Structural Management by Quantifying the Effect of Land Use and Land Cover on Watershed Runoff and Sediment Yield. Water Resources Management, 21, 1899-1913. http://dx.doi.org/10.1007/s11269-006-9136-x

[9] Birhanu, B.Z., Nodomba, P.M. and Mtalo, F.W. (2007) Application of SWAT Model for Mountainous Catchment. LARS Conference at Catchment at Arba Minch University, 2007, 182-187.

[10] Akhavan, S., Koupai, J.A., Mousavi, S., Afyuni, M., Eslamian, S. and Abbaspour, K.C. (2010) Application of SWAT Model to Investigate Nitrate Leaching in Hamadan Bahar Watershed, Lran. Agriculture, Ecosystems and Environment, 139, 675-688. http://dx.doi.org/10.1016/j.agee.2010.10.015

[11] Maharajan, G.R., Park, Y.S., Kim, N.W., Shin, D.S., Choi, J.W., Hyun, G.W., Jeon, J.H., Ok, Y.S. and Lim, K.J. (2012) Evaluation of SWAT Sub Daily Runoff Estimation at Small Agricultural Watershed in Korea. Frontiers of Environmental Sciences and Engineering, 7, 109-119. http://dx.doi.org/10.1007/s11783-012-0418-7

[12] Jain, S.K., Tyagi, J.V. and Singh, V. (2012) Simulation of Runoff and Sediment Yield for a Himalayan Watershed Using SWAT Model. Journal of Water Resources and Protection, 2, 267-281. http://dx.doi.org/10.4236/jwarp.2010.23031

[13] Shreshtha, N.K., Shakti, P.C. and Gurung, P. (2010) Calibration and Validation of SWAT Model for Low Lying Watersheds : A Case Study on the Kliene Nete Watershed, Belgium. Hydro Nepal, 6,47-51.

[14] Phomcha, P., Wirojanagud, P., Vangpaisal, T. and Thaveevouthti, T. (2011) Suitability of SWAT Model for Simulating of Monthly Stream Flow in Lam Sonthi Watershed. Journal of Industrial Technology, 7, 49-56.

[15] Arun Babu, E., Suresh, B. and Ravichandran, S. (2013) Application of SWAT Model to an Agricultural Watershed in Tamil Nadu, India. Proceeding of SWAT Conference 2012, IIT, Delhi, 16-20 July 2012, 120-132.

[16] Kaviya, K. and Ramalingam, M. (2012) Hydrological Cycle Simulation of Kodanavar River (Athur Block) Watershed Using Soil and Water Assessment Tool (SWAT). Proceeding of SWAT Conference 2012, IIT, Delhi, 16-20 July 2012, 109-117.

[17] Al-Muqdadi, S.W. and Merkel, B.J. (2011) Automated Watershed Evaluation of Flat Terrain. Journal of Water Re- 
sources and Protection, 3, 892-903. http://dx.doi.org/10.4236/jwarp.2011.312099

[18] Krause, P.D., Boyle, P. and Base, F. (2005) Comparison of Different Efficiency Criteria for Hydrological Model Assessment. Advanced Geo Science, 5, 89-97. http://dx.doi.org/10.5194/adgeo-5-89-2005 